\title{
Sources of resistance against the Pepper yellow mosaic virus in chili pepper
}

\author{
Cíntia dos S Bento ${ }^{1}$; Rosana Rodrigues ${ }^{1}$; Francisco Murilo Zerbini Júnior ${ }^{2}$; Cláudia P Sudré ${ }^{1}$ \\ ${ }^{1}$ UENF-CCTA, Lab. Melhoramento Genético Vegetal, Av. Alberto Lamego 2000, Parque Califórnia, 28013-602 Campos dos Goytacazes- \\ RJ; ' UFV-CCA, Dep ${ }^{\text {to }}$ Fitopatologia, 36570-000 Viçosa-MG; rosana@uenf.br; cdossantosbento@yahoo.com.br
}

\begin{abstract}
The Pepper yellow mosaic virus (PepYMV) naturally infects chili and sweet pepper, as well as tomato plants in Brazil, leading to severe losses. This work reports the reaction to the PepYMV of 127 Capsicum spp. accessions, aiming at identifying resistance sources useful in breeding programs. The experiment was carried out in a completely randomized design, with eight replications, in greenhouse conditions. Plants were protected with an insect-proof screen to avoid virus dissemination by aphids. Leaves of Nicotiana debneyi infected with the PepYMV were used as the inoculum source. Plants were inoculated with three to four fully expanded leaves. A second inoculation was done 48 hours later to avoid escapes. Only the youngest fully expanded leaf was inoculated. Two plants were inoculated only with buffer, as negative control. Symptoms were visually scored using a rating scale ranging from 1 (assymptomatic plants) to 5 (severe mosaic and leaf area reduction). Nine accessions were found to be resistant based on visual evaluation. Their resistance was confirmed by ELISA. Two resistance accessions belong to the species $C$. baccatum var. pendulum, while the seven other were $C$. chinense. No resistant accessions were identified in $C$. annuum var. annuum, C. annuum var. glabriusculum, and C. frutescens.
\end{abstract}

Keywords: Capsicum spp., Pepper yellow mosaic virus, Potyvirus, germplasm evaluation, disease resistance, pre-breeding.

\section{RESUMO}

Fontes de resistência ao Mosaico Amarelo do Pimentão em pimentas

O Mosaico Amarelo do Pimentão é causado pelo Pepper yellow mosaic virus (PepYMV) e tem ocorrência natural na maioria das regiões produtoras de pimenta, pimentão e tomate do Brasil, causando sérias perdas nas culturas de pimentão e pimenta. Este trabalho teve como objetivo avaliar a resistência de 127 acessos de Capsicum spp. ao PepYMV, com o intuito de identificar fontes de resistência a serem utilizadas em programas de melhoramento. O experimento foi conduzido em delineamento inteiramente casualizado, com oito repetições, em casa de vegetação, protegida com tela à prova de insetos, para evitar a disseminação do vírus por afídeos vetores. Folhas de Nicotiana debneyi infectadas com o PepYMV foram utilizadas como fonte de inóculo. Plântulas dos diferentes acessos foram inoculadas no estádio de três a quatro folhas definitivas e reinoculadas 48 horas após, para evitar escapes. Apenas as folhas mais jovens completamente expandidas foram inoculadas. Como controle negativo, duas plantas de cada acesso foram inoculadas apenas com solução tampão. A avaliação visual foi feita por meio de escala de notas de 1 (plantas assintomáticas) a 5 (plantas com sintomas severos de mosaico bolhoso e redução da área foliar). Nove acessos foram identificados como resistentes e, por meio do teste sorológico ELISA indireto, as plantas assintomáticas foram confirmadas como resistentes. Dois acessos resistentes pertencem à espécie Capsicum baccatum var. pendulum e, sete, à espécie Capsicum chinense. Não foram encontrados acessos resistentes de C. annиum var. annuит, C. annuиm var. glabriusculum e $C$. frutescens.

Palavras-chave: Capsicum spp., Pepper yellow mosaic vírus, Potyvirus, avaliação de germoplasma, resistência a doenças, pré-melhoramento.

\section{(Recebido para publicação em 7 de março de 2008; aceito em 6 de abril de 2009) (Received in March 7, 2008; accepted in April 6, 2009)}

$\mathrm{C}$ hili and sweet pepper belong to the genus Capsicum. Both crops have an increasing importance as a suitable alternative to small farmers, representing an incentive for family agriculture in Brazil (Ribeiro, 2004). Chili peppers represent a new market to Brazilian agriculture and to the food, pharmaceutical, and cosmetic industry. Products containing substances extracted from these species are currently used by a quarter of the global population, particularly for food seasoning (Carvalho et al., 2003).

In spite of the recent technological advances in chili pepper production systems, plant pathogens still rank among the key impediments for endproducts high yield and quality. Several fungi, bacteria, and virus diseases, occurring both in protected and nonprotected cultivation, are main causes of farmers' difficulties (Azevedo et al., 2005). The aphid-transmitted viruses caused by species of the genus Potyvirus, namely the Potato virus $Y$ (PVY), the Tobacco Eech virus (TEV), the Pepper veinal mottle virus (PVMV), the Chilli veinal mottle virus (ChiVMV), and the Pepper yellow mosaic virus (PepYMV) (Inoue-Nagata et al., 2001), impose severe losses to chili and sweet pepper production all around the world.

The PepYMV causes the yellow mosaic. The virus is present in most of the chili and sweet pepper (InoueNagata et al., 2002) and tomato (Cunha et al., 2004) production zones in Brazil. The disease is responsible for significant losses in the Brazilian Mid-West and Southeast regions, mainly in sweet pepper (Echer \& Costa, 2002; Zambolim et al., 2004). In tomato, Costa et al. (2003) estimated production losses ranging from 60 to $80 \%$ in fields at Venda Nova do Imigrante County (ES). The PepYMV 
was first reported in Brazil in 1980. It was at that moment named as PVYM , since it was supposed to be an aggressive PVY strain, able to break the resistance of some cultivars (Boiteux et al., 1996). Later, Inoue-Nagata et al. (2001) isolated and molecularly characterized some PVYM isolates. These studies confirmed a new Potyvirus species, named then Pepper Yellow Mosaic Virus.

The use of improved cultivars that bring together virus resistance, marketable fruit quality, and high yield is one of the most efficient alternatives for controlling the yellow mosaic. Therefore, breeding programs currently active in the country have been searching for resistance sources within Capsicum spp. germplasm banks. Sources of resistance to the PepYMV in Capsicum have been effective and longlasting under artificial inoculation in the field (Echer \& Costa, 2002). Resistant sweet pepper (Capsicum annuиm) cultivars are already available, such as the hybrid Magali R, considered as the commercial resistance pattern to the PepYMV (Truta et al., 2004), and the open-pollinated cultivars Myr-29 and Myr-10 (Echer \& Costa, 2002).

The objective of this research was to evaluate 127 Capsicum accessions of the Germplasm Bank of the State University of Norte Fluminense Darcy Ribeiro (UENF). The target was to identify new sources of resistance to the PepYMV to be included in Capsicum breeding programs.

\section{MATERIAL AND METHODS}

Plant material and growing conditions - The experiments were carried out in the area used under an Agreement signed by the State University of Norte Fluminense (UENF) and the Agricultural Research Corporation of the State of Rio de Janeiro (PESAGRO-RIO), Experimental Station of Campos, in Campos dos Goytacazes County, Rio de Janeiro State, in two steps, from May to November, 2007. We evaluated 127 accessions (Table 1), which had been previously agronomic and morphologically characterized (Sudré et al., 2005; Bento et al., 2007; Lima et al., 2007). The susceptible sweet pepper cultivar Ikeda (Ávila et al., 2004) was used as positive control.

Seeds of the accessions and cultivar Ikeda were sown in 128-cell polystyrene foam trays with organic substrate (Plantmax $^{\circledR}$ ). Upon developing two pair of leaves, plantlets were individually transferred to plastic pots filled with a mixture of soil and substrate $(2: 1)$. The experiment was carried out in cages covered with aphid-proof screens to avoid virus dissemination by vectors, in greenhouse. The average temperature ranged between $27.6^{\circ} \mathrm{C}$ (day) to $21.5^{\circ} \mathrm{C}$ (night). Each accession was replicated eight times, in a completely randomized design, numbering 1016 plants.

Inoculation and evaluation of resistance to the PepYMV - The inoculum source consisted of plants of Nicotiana debneyi mechanically inoculated with the PepYMV-3 isolate, collected in sweet pepper, in Igarapé County, Minas Gerais State (Truta et al., 2004). Plants under evaluation, including cultivar Ikeda, were inoculated using extracts of the inoculum source, prepared in potassium phosphate buffer $0.05 \mathrm{M}$, $\mathrm{pH} 7.2$, with sodium sulphate $0.01 \%$. Carborundum (600 mesh) was used as abrasive (Truta et al., 2004). Inoculum extracts were prepared using $1.0 \mathrm{~g}$ of infected leaves in $1.0 \mathrm{~mL}$ of buffer. Plants were inoculated when presenting three to four fully expanded leaves, and reinoculated 48 hours later, to avoid infection escape. Only the youngest and fully developed leaf was inoculated in each plant. Two plants of each accession were inoculated exclusively with buffer, as a negative control.

Evaluation began 15 days after the first inoculation, when symptoms started appearing, and went on every other day, up to 39 days after the first inoculation. Symptoms were visually assessed using a rating scale (Bento, 2008), developed on preliminary pilot experiments, as follows: score $1=$ symptomless plants; 2 = plants showing slight symptoms (up to $25 \%$ of the leaf area with small mosaic dots); 3 = plants showing moderate symptoms (up to $50 \%$ of the leaf area with mosaic); $4=$ strong symptoms (up to $75 \%$ of the leaf area with mosaic); and $5=$ severe symptoms $(100 \%$ of the leaf area with mosaic, leaves displaying swelling and curling, and reduction of leaf area). Analysis of variance and the means clustering test of Scott-Knott were performed using the software GENES (Cruz, 2006).

Accessions with score 1 in this first assay were re-evaluated using the same methodology. To confirm accessions resistance to the PepYMV, symptomless plants were submitted to indirect ELISA (Enzyme-linked immunosorbent assay) (Clark et al., 1986), using a polyclonal antiserum produced against the isolate PepYMV-3 (Truta et al., 2004). Indirect ELISA was carried out at the Plant Virology Laboratory, Federal University of Viçosa (UFV), in Viçosa County, Minas Gerais State. To perform ELISA, we used $0.5 \mathrm{~g}$ of plant tissue collected in 4 to 6 young leaves from the Capsicum accessions that re-scored 1 in the second assay, as well as from the positive and negative controls, and from $N$. debneyi plants infected with the PepYMV. Leaves were crushed in a mortar, with $2.5 \mathrm{~mL}$ of extraction buffer (1:5 dilution). Plant extracts were stored in labeled flasks and kept at $-20^{\circ} \mathrm{C}$ until using. Four $100 \mu \mathrm{l}$ replications per accession, per plate, were used. Antiserum was diluted to 1:10.000, and, the conjugate, to 1:2000, both in PEP buffer (Clark et al., 1986). After adding the substrate ( $p$-nitrofenilfosfato, $1 \mathrm{mg} \mathrm{mL}^{-1}$ ), plates were kept at room temperature, in the dark, for 30 minutes. Following, the color intensity developed as consequence of the enzymatic reaction was assessed using a Titertek Multiskan Plus MK II data logger, at $405 \mathrm{~nm}$. Absorbance values lower than twice the negative control (healthy plants) were considered as indication of virus absence in the sample (Sutula et al. (1986).

\section{RESULTS AND DISCUSSION}

Virus symptoms were observed in several plant growing stages, confirming the virulence of isolate PepYMV-3. There were significant differences among the 127 Capsicum spp. accessions in relation to resistance to the PepYMV, ranging from absence of symptoms (score 1) to leaf distortion and swelling mosaic (score 5). Such variation 
Table 1. Code number, species, origin, and average of scores of 128 Capsicum accessions assessed for resistance against the Pepper yellow mosaic virus - PepYMV (número de registro, espécie, procedência e médias das notas dos 128 acessos de Capsicum spp. testados quanto à resistência ao PepYMV). Campos dos Goytacazes, UENF, 2007.

\begin{tabular}{|c|c|c|c|c|c|c|c|}
\hline $\begin{array}{l}\text { UENF } \\
\text { Code }\end{array}$ & Species & Origin & $\begin{array}{c}\text { Score } \\
\text { Average }\end{array}$ & $\begin{array}{l}\text { UENF } \\
\text { Code }\end{array}$ & Species & Origin & $\begin{array}{c}\text { Score } \\
\text { Average }^{1}\end{array}$ \\
\hline 1553 & C. chinense & Goiânia, GO & $5 a$ & 1784 & C. chinense & São Luís, MA & $3 c$ \\
\hline 1615 & C. chinense & Viçosa, MG & $5 a$ & 1786 & C. chinense & São Luís, MA & $3 c$ \\
\hline 1630 & C. baccatum var. pendulum & Campos, RJ & $5 a$ & 1789 & C. chinense & São Luís, MA & $3 c$ \\
\hline 1735 & C. baccatum var. pendulum & Viçosa, MG & $5 a$ & 1790 & C. frutescens & São Luís, MA & $3 c$ \\
\hline 1743 & C. chinense & Marajó-Souré, PA & $5 a$ & 1797 & C. baccatum var. pendulum & Viçosa, MG & $3 c$ \\
\hline 1800 & C. frutescens & Bequimão, MA & $5 a$ & 1799 & C. annuum var. annuum & Bequimão, MA & $3 c$ \\
\hline 1810 & Capsicum sp. & Campos, RJ & $5 a$ & 1805 & C. chinense & Campos, RJ & $3 c$ \\
\hline 1417 & C. chinense & Campos, RJ & $4 \mathrm{~b}$ & 1422 & C. annuum var. annuum & Topseed & $2 d$ \\
\hline 1424 & C. chinense & Campos, RJ & $4 \mathrm{~b}$ & 1490 & C. frutescens & Rio de Janeiro, RJ & $2 d$ \\
\hline 1426 & C. chinense & Campos, RJ & $4 \mathrm{~b}$ & 1498 & C. chinense & Rio de Janeiro, RJ & $2 d$ \\
\hline 1497 & C. chinense & Campos, RJ & $4 \mathrm{~b}$ & 1503 & C.chinense & México & $2 d$ \\
\hline 1499 & C. chinense & Campos, RJ & $4 \mathrm{~b}$ & 1611 & C. baccatum var. pendulum & Viçosa, MG & $2 d$ \\
\hline 1559 & C.annuum var. glabriusculum & $\begin{array}{l}\text { Cachoeira de } \\
\text { Macacu,RJ }\end{array}$ & $4 \mathrm{~b}$ & 1612 & C. baccatum var. pendulum & Viçosa, MG & $2 d$ \\
\hline 1612 & C. baccatum var. pendulum & Viçosa, MG & $4 \mathrm{~b}$ & 1616 & C. baccatum var. pendulum & Viçosa, MG & $2 d$ \\
\hline 1613 & C. baccatum var. pendulum & Viçosa, MG & $4 \mathrm{~b}$ & 1618 & C. chinense & Viçosa, MG & $2 d$ \\
\hline 1615 & C. chinense & Viçosa, MG & $4 \mathrm{~b}$ & 1631 & C. baccatum var. pendulum & Celina, ES & $2 d$ \\
\hline 1622 & C. annuum var. annuum & Estados Unidos & $4 \mathrm{~b}$ & 1634 & C. chinense & Vargem Alta, ES & $2 d$ \\
\hline 1628 & C. baccatum var. pendulum & Campos, RJ & $4 \mathrm{~b}$ & 1636 & C. frutesces & Miranda, MS & $2 d$ \\
\hline 1629 & C. baccatum var. pendulum & Campos, RJ & $4 \mathrm{~b}$ & 1637 & C. baccatum var. pendulum & Miranda, MS & $2 d$ \\
\hline 1639 & C. baccatum var. pendulum & Feltrin Sementes & $4 \mathrm{~b}$ & 1714 & C. baccatum var. pendulum & Peru & $2 d$ \\
\hline 1722 & C. chinense & Ilhéus, BA & $4 \mathrm{~b}$ & 1715 & C. chinense & Peru & $2 d$ \\
\hline 1723 & C. chinense & Campos, RJ & $4 \mathrm{~b}$ & 1719 & C. baccatum var. pendulum & Renascença, PR & $2 d$ \\
\hline 1752 & C. chinense & Ilhéus, BA & $4 \mathrm{~b}$ & 1731 & C. frutescens & Petrolina, PE & $2 d$ \\
\hline 1771 & C. chinense & Bequimão, MA & $4 \mathrm{~b}$ & 1733 & C. baccatum var. pendulum & Campos, RJ & $2 d$ \\
\hline 1772 & C. chinense & Bequimão, MA & $4 \mathrm{~b}$ & 1736 & C. chinense & São Domingos, ES & $2 d$ \\
\hline 1774 & C. chinense & Bequimão, MA & $4 \mathrm{~b}$ & 1737 & C. baccatum var. pendulum & $\begin{array}{l}\text { Cachoeira de } \\
\text { Macacu, RJ }\end{array}$ & $2 d$ \\
\hline 1779 & C. frutescens & Bequimão, MA & $4 \mathrm{~b}$ & 1745 & C. chinense & Marajó-Souré, PA & $2 d$ \\
\hline 1567 & C. annuum var. annuum & Bahia, BA & $3 c$ & 1746 & C. chinense & Marajó-Souré, PA & $2 d$ \\
\hline 1623 & C. annuum var.annuum & Campos, RJ & $3 c$ & 1747 & C. frutescens & Marajó-Souré, PA & $2 d$ \\
\hline 1625 & C. baccatum var. pendulum & Campos, RJ & $3 c$ & 1750 & C. annuum var. glabriusculum & Campos, RJ & $2 d$ \\
\hline 1626 & C. annuum var. annuum & Campos, RJ & $3 c$ & 1762 & C. chinense & Belém, PA & $2 d$ \\
\hline 1633 & C. baccatum var. pendulum & Campos, RJ & $3 c$ & 1763 & C. chinense & Belém, PA & $2 d$ \\
\hline 1704 & C. baccatum var. pendulum & Viçosa, MG & $3 c$ & 1767 & C. chinense & Belém, PA & $2 d$ \\
\hline 1707 & C. chinense & São Luis, MA & $3 c$ & 1768 & C. chinense & Belém, PA & $2 d$ \\
\hline 1709 & C. chinense & São Luis, MA & $3 c$ & 1775 & C. frutescens & Bequimão, MA & $2 d$ \\
\hline 1716 & C. chacoense & Argentina & $3 c$ & 1785 & C. chinense & São Luís, MA & $2 d$ \\
\hline 1717 & C. annuum var annuum & Renascença, PR & $3 c$ & 1788 & C. chinense & São Luís, MA & $2 d$ \\
\hline 1718 & C. baccatum var pendulum & Renascença, PR & $3 c$ & 1790 & C. frutescens & São Luís, MA & $2 d$ \\
\hline 1721 & C. chinense & Ilhéus, BA & $3 c$ & 1792 & C. chinense & São Luís, MA & $2 d$ \\
\hline 1725 & C. chinense & Ilhéus, BA & $3 c$ & 1793 & C. chinense & São Luís, MA & $2 d$ \\
\hline 1726 & C. chinense & Ilhéus, BA & $3 c$ & 1794 & C. chinense & São Luís, MA & $2 d$ \\
\hline 1727 & C. frutescens & Ilhéus, BA & $3 c$ & 1798 & C. chinense & Campos, RJ & $2 d$ \\
\hline 1744 & C. chinense & Marajó-Souré, PA & $3 c$ & 1802 & C. frutescens & Campos, RJ & $2 d$ \\
\hline 1748 & C. chinense & Marajó-Souré, PA & $3 c$ & 1806 & C. chinense & Campos, RJ & $2 d$ \\
\hline 1749 & C. chinense & Campos, RJ & $3 c$ & 1808 & Capsicum sp. & Campos, RJ & $2 d$ \\
\hline 1753 & C. chinense & Ilhéus, BA & $3 c$ & 1811 & Capsicum sp. & Campos, RJ & $2 d$ \\
\hline 1757 & C. chinense & Ilhéus, BA & $3 c$ & 1812 & Capsicum sp. & Campos, RJ & $2 d$ \\
\hline 1758 & C. chinense & Ilhéus, BA & $3 c$ & 1624 & C. baccatum var. pendulum & Campos, RJ & $1 \mathrm{e}$ \\
\hline 1761 & C. chinense & Belém, PA & $3 c$ & 1755 & C. chinense & Peru & $1 \mathrm{e}$ \\
\hline 1765 & C. chinense & Belém, PA & $3 c$ & 1764 & C. chinense & Belém, PA & $1 \mathrm{e}$ \\
\hline 1766 & C. frutescens & Belém, PA & $3 c$ & 1770 & C. chinense & Belém, PA & $1 \mathrm{e}$ \\
\hline 1773 & C. chinense & Bequimão, MA & $3 c$ & 1703 & C. chinense & Viçosa, MG & $1 \mathrm{e}$ \\
\hline 1776 & C. frutescens & Rosário, MA & $3 c$ & 1730 & C. chinense & Peru & $1 \mathrm{e}$ \\
\hline 1780 & C. chinense & Bequimão, MA & $3 c$ & 1732 & C. baccatum var. pendulum & Campos, RJ & $1 \mathrm{e}$ \\
\hline 1781 & C. chinense & Bequimão, MA & $3 c$ & 1751 & C. chinense & Parintins, AM & $1 \mathrm{e}$ \\
\hline 1782 & C. chinense & Bequimão, MA & $3 c$ & 1803 & C. chinense & Campos, RJ & $1 \mathrm{e}$ \\
\hline
\end{tabular}

${ }^{1}$ Means followed by the same letter in each column did not differ significantly from each other, Scott \& Knott clustering test, $\mathrm{p}<0.01$ (médias seguidas das mesmas letras em cada coluna não diferem significativamente entre si, teste de agrupamento de $\mathrm{Scott} \& \mathrm{Knott}$, p<0,01). 
reveals the diversity present within the germplasm assessed regarding resistance to the PepYMV. Nine accessions did not develop symptoms and were scored as 1 (Table 1). Among these, two accessions were Capsicum baccatum var. pendulum (UENF1624 and UENF1732) and, seven, $C$. chinense (UENF1703, UENF1730, UENF1732, UENF1751, UENF1755, UENF1764 and UENF1803). The $C$. baccatum accessions were both collected in Campos dos Goytacazes, Rio de Janeiro State, while $C$. chinense had several origins: one accession came from Viçosa County, Minas Gerais State; two from Pará State (UENF1764 and UENF1770, from Belém County); one from Amazonas State (UENF1751, from Parintins County); and two from Peru (UENF1730 and UENF1755) (Table 1). Cunha et al. (2004) had previously identified two $C$. chinense accessions, PI159236 and PI152225, as sources of resistance to the PepYMV. Nevertheless, as far as we are concerned, no resistance sources have been described yet in C. baccatum.

Following the identification of the symptomless accessions, the serological indirect ELISA was carried out to confirm the resistance to the PepYMV. Symptom development in inoculated plants is dependent on the virus isolate, cultivar, and environmental conditions (Rowhani, 1997). The remaining accessions were susceptible, developing typical symptoms, and were not submitted to ELISA.

Capsicum plants inoculated only with buffer and Nicotiana debneyi plants infected with isolates PepYMV-3 and PepYMV-11 correspond respectively to ELISA negative and positive controls. Results reconfirmed accessions resistance to the PepYMV: the average absorbance values of samples coming from symptomless plants were below the threshold, namely, twice the average of the negative control. Therefore, those plants were not infected by PepYMV, according to the methodology suggested by Sutula $\mathrm{et} \mathrm{al}$. (1986) (Table 2). Positive controls had high absorbance values, attesting that ELISA was properly performed and the antiserum was effective in recognizing the virus isolate. Accessions found as

Table 2. Code number, species, absorbance values for indirect ELISA, and final evaluation of nine Capsicum sp. accessions assessed for resistance to the Pepper yellow mosaic virus (número de registro, espécie, valores de absorbância para ELISA indireto e avaliação final de nove acessos de Capsicum spp. testados quanto à resistência ao PepYMV). Campos dos Goytacazes, UENF, 2007.

\begin{tabular}{|c|c|c|c|c|}
\hline $\begin{array}{l}\text { Code } \\
\text { number }\end{array}$ & Species & Absorbance & ${ }^{1}$ ELISA & $\begin{array}{c}{ }^{2} \text { Final } \\
\text { evaluation }\end{array}$ \\
\hline 1624 & C. baccatum var. pendulum & 0,142 & - & $\mathrm{R}$ \\
\hline 1703 & C. chinense & 0,145 & - & $\mathrm{R}$ \\
\hline 1730 & C. chinense & 0,131 & - & $\mathrm{R}$ \\
\hline 1732 & C. baccatum var. pendulum & 0,132 & - & $\mathrm{R}$ \\
\hline 1751 & C. chinense & 0,141 & - & $\mathrm{R}$ \\
\hline 1755 & C. chinense & 0,106 & - & $\mathrm{R}$ \\
\hline 1764 & C. chinense & 0,179 & - & $\mathrm{R}$ \\
\hline 1770 & C. chinense & 0,163 & - & $\mathrm{R}$ \\
\hline 1803 & C. chinense & 0,150 & - & $\mathrm{R}$ \\
\hline $1624(-)$ & C. baccatum var. pendulum & 0,174 & - & - \\
\hline $1703(-)$ & C. chinense & 0,127 & - & - \\
\hline $1730(-)$ & C. chinense & 0,115 & - & - \\
\hline $1732(-)$ & C. baccatum var. pendulum & 0,155 & - & - \\
\hline $1751(-)$ & C. chinense & 0,289 & - & - \\
\hline $1755(-)$ & C. chinense & 0,238 & - & - \\
\hline $1764(-)$ & C. chinense & 0,302 & - & - \\
\hline $1770(-)$ & C. chinense & 0,306 & - & - \\
\hline $1803(-)$ & C. chinense & 0,209 & - & - \\
\hline N. debneyi (-) & Nicotiana debneyi & 0,333 & - & - \\
\hline N. debneyi (-) & Nicotiana debneyi & 0,326 & - & - \\
\hline $1422(+)$ & C. annuum var. annuum cv. Ikeda & 0,711 & + & $\mathrm{S}$ \\
\hline Isolado $3(+)$ & Nicotiana debneyi & 1,468 & + & $\mathrm{S}$ \\
\hline Isolado $11(+)$ & Nicotiana debneyi & 1,259 & + & $S$ \\
\hline
\end{tabular}

${ }^{1}(+)=$ Positive reaction to the virus presence (reação positiva à presença do vírus); $(-)=$ negative reaction to the virus presence (reação negativa à presença do vírus); ${ }^{2} \mathrm{R}=$ resistance (resistência); $\mathrm{S}=$ susceptibility (suscetibilidade).

resistant in the first assay behave as resistant also in a second assay, carried out using the same inoculation and evaluation protocols as before, both in visual evaluation and ELISA. No plants showed late infection or restriction of symptoms to isolated plant parts.

According to the rating scale, some accessions were more susceptible than cultivar Ikeda, the susceptible control. However, due to the large number of plants, we did not submit plants with symptoms to ELISA. Thus, no comparisons of the absorbance values of these accessions were made. Nevertheless, symptoms observed in susceptible plants were clear enough to unquestionably consider them as susceptible.

In Capsicum spp., the first promising sources of resistance to the PepYMV were $C$. annuum cultivar Criollo de
Morellos 334 (CM334, monogenic dominant resistance) and $C$. chinense PI 159236 (monogenic recessive resistance) (Boiteux \& Pessoa, 1994; Boiteux et al., 1996). Nonetheless, in spite of the broad literature survey, we did not find reports of resistance to the PepYMV in C. baccatum. Thus, this report is likely to be the first ever. Additional investigation about the inheritance of resistance by means of intra and interspecific crosses, in $C$. baccatum and C. annuum backgrounds, respectively, must be carried out to identify the number of genes involved in the reaction, as well as other genetic parameters important to breeders. Molecular techniques are helpful in characterizing the resistance sources described here. PCR-based molecular markers able to detect some PepYMV resistance genes are already available. This is the case for allele Pvr4, original 
from C. annuum accession CM-334, which was mapped to sweet pepper chromosome 10 (Grube et al., 2000): there is a marker only 2,1 $\pm 0,8 \mathrm{cM}$ away from allele Pvr4 (Caranta et al., 1999; ArnedoAndrés et. al., 2002).

Although $C$. baccatum and $C$. annuиm are clustered in distinct gene pools, crossings between the two species had been successfully made (Campos, 2006). Therefore, the transference and pyramiding of resistance genes from one species to the other is expected to be feasible. It should be highlighted that the search for resistance to the PepYMV is important not only to sweet and chili peppers, but also to tomato. Contrary to what is found in Capsicum, in which resistance sources have already been identified in C. annuum, in commercial terms the most important species in the genus, $C$. chinense, and now in C. baccatum, in tomato, Juhász et al. (2006) did not find resistance among the 355 Lycopersicon esculentum accessions studied and, among 21 wild relatives, only a single accession of L. hirsutum was resistant. Lourenção et al. (2005) identified only two sources of resistance to Potyvirus in tomato when assessing 16 tomato genotypes. On the other hand, in Capsicum, Nascimento et al. (2007), found resistance to the PepYMV in six experimental and one commercial hybrids out of 26 genotypes.

In sweet pepper, mostly in regions where PepYMV outbreaks take place regularly, as in Espírito Santo State (Inoue-Nagata et. al., 2003), it was noticed that sweet and chili pepper pictures are similar to tomato: cultivars with no genetic resistance to the pathogen prevail. Regarding sweet pepper, some resistant hybrids are already available in the market. However, the incorporation of resistance into hybrids that correspond to commercial requirements of distinct markets must be encouraged (Ávila et al., 2004). The resistant accessions reported in this paper are useful in breeding programs that target at the incorporation of resistance genes into the process of both sweet and chili pepper cultivar development.

\section{ACKNOWLEDGMENTS}

Authors thank the State University of Norte Fluminense Darcy Ribeiro for the M.Sc. scholarship granted to the first author. Thanks also to the graduate students Leandro Simões Azeredo Gonçalves, Sarah Ola Moreira, and Kenea Coelho, as well as to the technician José Manoel Miranda and his team, for the valuable help in carrying out this work.

\section{REFERENCES}

ARNEDO-ANDRÉS MS; GIL-ORTEGA R; LUIS-ARTEAGA M; HORMAZA JI. 2002. Development of RAPD and SCAR markers linked to the Pvr4 locus for resistance to PVY in pepper (Capsicum annuum L.). Theoretical and Applied Genetics 105:1067-1074.

ÁVILA AC; INOUE-NAGATA AK; COSTA H; BOITEUX LS; NEVES LOQ; PRATES RS; BERTINI LA. 2004. Ocorrência de viroses em tomate e pimentão na região serrana do estado do Espírito Santo. Horticultura Brasileira 22: 655-658.

AZEVEDO CP; CAFÉ FILHO AC; HENZ GP; REIS A. 2005. Pimentão: Antracnose arrasadora. Cultivar HF, p. 18-20.

BENTO CS. 2008. Identificação de fontes de resistência ao Pepper Yellow Mosaic Virus em Capsicum spp. e resposta ecofisiológica de acessos de Capsicum chinense infectados com esse vírus. Campos dos Goytacazes: UENF. 97p (Tese mestrado).

BENTO CS; SUDRÉ CP; RODRIGUES R; RIVA EM; PEREIRA MG. 2007. Descritores qualitativos e multicategóricos na estimativa da variabilidade fenotípica entre acessos de pimentas. Scientia Agraria 8: 146-153.

BOITEUX LS; CUPERTINO FP; SILVA C; DUSI AN; MONTE-NESHICH DC. 1996. Resistance to Potato virus $Y$ (pathotype 12) in Capsicum annuum and Capsicum chinense is controlled by two independent major genes. Euphytica 87: 53-58.

BOITEUX LS; PESSOA HBSV. 1994. Additional sources of resistance to isolates of $\mathrm{PVY}^{\mathrm{m}}$ in Capsicum germoplasm. Fitopatologia Brasileira, v.19 (suplemento), p.291, Resumos.

CAMPOS KP. 2006. Obtenção, caracterização molecular, morfológica e reprodutiva de híbridos entre espécies de Capsicum. Campos dos Goytacazes: UENF. 145p (Tese doutorado).

CARANTA C; THABUIS A; PALLOIX A. 1999. Development of a CAPS marker for the Pvr4 locus: a tool for pyramiding potyvirus resistance genes in pepper. Genome 42: 1111-1116.
CARVALHO SIC; BIANCHETTI LB; BUSTAMANTE PG; SILVA DB. 2003. Catálogo de germoplasma de pimentas e pimentões (Capsicum spp.) da Embrapa Hortaliças. Brasília: Embrapa Hortaliças. 49p.

CLARK MF; LISTER RM; BAR-JOSEPH M. 1986. ELISA techniques. Methods in Enzymology 118: 742-766.

COSTA H; VENTURA JA; ZAMBOLIN EM; BASTOS JVB; CALIMAN L. 2003. Distribuição do Pepper yellow mosaic virus (PepYMV) em tomateiro na região serrana do Espírito Santo. Fitopatologia Brasileira 28: 247-248.

CRUZ CD. 2006. Programa Genes versão Windows. Aplicativo Computacional em Genética e Estatística. Viçosa: UFV. 648p.

CUNHA LCV; RESENDE RO; NAGATA T; INOUE-NAGATA AK. 2004. Distinct features of Pepper yellow mosaic virus isolates from tomato and sweet pepper. Fitopatologia Brasileira 29: 663-667.

ECHER MM; COSTA CP. 2002. Reaction of sweet pepper to the Potato virus $Y\left(\mathrm{PVY}^{\mathrm{M}}\right)$. Scientia Agricola 59: 309-314.

GRUBE RC; BLAUTH JR; ARNEDOANDRÉS MS; CARANTA C; JAHN MK. 2000. Identification and comparative mapping of a dominant potyvirus resistance gene cluster in Capsicum. Theoretical Applied Genetics 101:852-859.

INOUE-NAGATA AK; FONSECA MEN; LOBO TOTA; ÁVILA AC; MONTE DC. 2001. Analysis of the nucleotide sequence of the coat protein and 3' untranslated region of two Brazilian Potato virus Y isolates. Fitopatologia Brasileira 26: 4552.

INOUE-NAGATA AK; FONSECA MEN; RESENDE RO; BOITEUX LS; MONTE DC; DUSI AN; ÁVILA AC; VLUGT RAA. 2002 Pepper yellow mosaic virus, a new potyvirus in sweetpepper, Capsicum annuum. Archives of Virology 147: 849855.

INOUE-NAGATA AK; HENZ GP; RIBEIRO CSC; ÁVILA AC. 2003. Occurrence of Pepper yellow mosaic virus - Potyvirus in sweet pepper, pepper, and tomato plants in Brazil. Virus Reviews \& Research 8: 186187.

JUHÁSZ ACP; SILVA DJH; ZERBINI FM; SOARES BO; AGUILERA GAH. 2006. Screening of Lycopersicon sp. accessions for resistance to Pepper yellow mosaic virus. Scientia Agricola 63: 510-512.

LIMA MCC; SUDRÉ CP; POLTRONIERI MC; GONÇALVES LSA; PEREIRA TNS; RODRIGUES R. 2007. Recursos genéticos em Capsicum: estudo da diversidade genética de quatro espécies domesticadas e três silvestres e suas estruturas florais. Brasília: Embrapa (Comunicado Técnico).

LOURENÇÃO AL; SIQUEIRA WJ; MELO AMT; PALAZZO SRL. 2005. Resistência de cultivares e linhagens de tomateiro a Tomato chlorotic spot virus e a Potato virus Y. Fitopatologia Brasileira 30: 609-614. 
NASCIMENTO IR; VALLE LAC; MALUF WR; GONÇALVES LD; GOMES LAA; MORETO P; LOPES EAGL. 2007. Reação de híbridos, linhagens e progênies de pimentão à requeima causada por Phytophthora capsici e ao mosaico amarelo causado por Pepper yellow mosaic virus (PepYMV). Ciência Agrotecnologia 31: 121-128.

RIBEIRO CSC. 2004. Pesquisa em Capsicum spp. na Embrapa. In: Encontro Nacional do Agronegócio Pimenta (Capsicum spp), 1., Brasília. Brasília: Embrapa Hortaliças, p.10 (CD-ROM).
ROWHANI A; UYEMOTO JK; GOLINO DA 1997. A comparison between serological and biological assays in detecting grapevine leafroll associated vírus. Plant Disease 81: 799-801.

SUDRÉ CP; RODRIGUES R; RIVA EM; KARASAWA M; AMARAL JUNIOR AT. 2005. Divergência genética entre acessos de pimenta e pimentão utilizando técnicas multivariadas. Horticultura Brasileira 23: 22-27.

SUTULA CL; GILLET JM; MORRISSEY SM; RAMSDELL DC. 1986. Interpreting ELISA data and establishing the positive-negative threshold. Plant Disease 70: 722-726.
TRUTA AAC; SOUZA ARR; NASCIMENTO AVS; PEREIRA RC; PINTO CMF; BROMMONSCHENKEL SH; CARVALHO MG; ZERBINI FM. 2004. Identidade e propridades de isolados de potyvírus provenientes de Capsicum spp. Fitopatologia Brasileira 29: 160-168.

ZAMBOLIM EM; COSTA H; CAPUCHO AS; AVILA AC; INOUE-NAGATA AK; KITAJIMA EW. 2004. Surto epidemiológico do vírus do mosaico amarelo do pimentão em tomateiro na região Serrana do Estado do Espírito Santo. Fitopatologia Brasileira 29: 325-327. 